\title{
Human Papillomavirus mRNA
}

National Cancer Institute

\section{Source}

National Cancer Institute. Human Papillomavirus mRNA. NCI Thesaurus. Code C156861.

Any RNA molecule that is the product of transcription of a human papillomavirus gene and contains coding information that can be translated into the amino acid sequence of a protein. 